
Society

\title{
Do ecosystem services provide an added value compared to existing forest planning approaches in Central Europe?
}

\author{
Markus A. Meyer ${ }^{1}$ and Christoph Schulz ${ }^{1}$
}

\begin{abstract}
In forestry research, the concept of ecosystem services (ESS) is less prominent than in agricultural studies. One reason might be that multifunctional forestry and the concept of forest functions, i.e., societal demand from forest, are established and legally required planning approaches in Central Europe, e.g., in Germany, Austria, and Switzerland. To explore differences in concept and perspective, we conducted a participatory stakeholder workshop to identify, score, and map ESS in an urban forest in Germany. For comparison, we used existing forest function maps. Forest function mapping as planning approach is based on a regional-scale expert assessment of forest agencies. The local ESS scoring showed a clear preference for recreation, drinking water, biodiversity, mediation of climate and water, and wood provision in decreasing order. Most stakeholder groups scored recreation highest. Drinking water was also important for most stakeholders. Recreation stakeholders scored unbalanced with an apparent focus on their own demand (Gini coefficient: 0.83). Contrastingly, forestry stakeholders scored the ESS in a balanced manner (Gini coefficient: 0.47). ESS and forest function maps highly overlapped. The stakeholders identified both synergies and trade-offs between timber and biodiversity and between drinking water and biodiversity depending on the management. Recreation has mostly trade-offs, with timber, hunting, and drinking water. The stakeholders mapped only few ESS in addition to forest functions, e.g., feed production, beekeeping, and biodiversity hotspots. Although forest functions consider most forest benefits despite weak stakeholder consultation, the opportunity to prioritize forest benefits and to analyze interactions is a clear added value of the ESS approach. The paradigm of simultaneous provision of all forest functions does not reflect heterogeneous societal preferences. The stakeholders showed a rather low level of conflict and a high level of understanding for differences in their prioritization. The reason might be the long local tradition of multiple-use forestry beginning in the late 1800s. The study area is an example for an urban forest of a larger city in Europe with high pressure from local recreation. It would be interesting to test the approach for other environmental conditions and locations of an urban forest. In general, the developed approach could be used to evaluate the quality of other planning instruments for multiple-use forestry worldwide regarding their consideration of stakeholder requirements and the potential added value of the ESS approach.
\end{abstract}

Key Words: ecosystem services; forest functions; forestry; participatory GIS; preferences; stakeholders

\section{INTRODUCTION}

There are numerous potential foci for spatial assessments of ecosystem services (ESS), i.e., the human benefits from the environment (MEA 2005). They may focus on mixed landscapes, on natural or human-modified ecosystems, or on selected landuse classes, e.g., forest or agricultural land (Haase et al. 2014). Most studies map ESS for agriculture rather than forestry (Malinga et al. 2015). There may be multiple reasons why forestry is underrepresented.

For a Central European perspective, multifunctional forestry extended the focus from timber to multiple human benefits from forests (McArdle 1953, Ammer and Püttmann 2009, GrêtRegamey et al. 2013, Kindler 2016). In addition, the concept of forest functions, i.e., societal demand from forests, and its implementation in forest-function maps are well-established and legally required planning instruments in German-speaking countries (Pistorius et al. 2012). Nevertheless, both the Ministerial Conference on the Protection of Forests in Europe (today: Forest Europe) and the UN use in their definition of sustainable forest management the terms of ecological, economic, and social functions of forests (Kindler 2016). Forest functions partly overlap with the ESS concept. This overlap raises the question of possible gains for forest planning from ESS as an additional concept to quantify the human benefit from forests. In Germany, the federal states comprehensively mapped and assessed forest functions for the first time in the 1970s and regularly update the maps (Kindler 2016). Forest functions are the main justification to maintain and increase the forest area according to $\S 1$ of the German Federal Forest Act. However, it only specifies the main categories: use, protective, and recreational functions. The German federal states cooperate to harmonize forest function mapping on a voluntary basis, but they implement it by individual state laws and guidelines (Wirth et al. 2015). Forest functions are mapped for state, communal, or private forests and all forest owners should consider forest functions in forest management. Forest functions maps are mostly only binding for communal and state forests, e.g., in the German Federal State of Bavaria (StMELF 2015). The concept extends the purpose of forest management beyond obvious benefits from forests such as timber (Pistorius et al. 2012). The mentioned forest function categories of use, protective, and recreational functions are partly comparable to the ESS concept (Kindler 2016) with its provisioning, regulating, and cultural ESS. In contrast to the environmental science-centric ESS concept (Kindler 2016), forest functions serve as regional planning tool (StMELF 2013). In addition, forest agencies designate forest functions based on assessments and planning instruments from other public agencies. For example, water or nature protection areas are equally included as forest functions, which are not designated by forest agencies but rather by water or nature protection agencies (Bürger-Arndt et al. 2012).

We address two research gaps. (i) Despite or because of these communalities of forest functions and ESS, existing research only conceptually compares them (Pistorius et al. 2012, Kindler 2016). 
Studies that compare ESS and forest function assessments on the ground hardly exist. Such comparison might give an insight, to which extent the ESS concept may provide an added value to the existing quantification of forest benefits. If there is no added value from the ESS concept, it may be possible to rely on existing assessments of forest functions instead of conducting comparable ESS assessments for forests such as the ongoing numerous national or regional ESS assessments (Wong et al. 2015). (ii) The mapping of forest functions seems to persist with few innovations if considering the low number of publications since its implementation in the 1970s, which is the opposite for the ESS concept (Kindler 2016). Therefore, the reliability of the approach and the consideration of relevant functions should be evaluated.

To identify a suitable comparison of a forest function and an ESS assessment for this purpose, it is necessary to understand the forest function mapping procedure. Existing forest function maps are based on expert assessments (Bürger-Arndt 2013), which are conducted in a standardized way by forest agencies of the respective German federal states for all categories of forest ownership and locations. However, the mapping approaches differ between the federal states despite harmonization efforts (Wirth et al. 2015). The forest function mapping is mostly limited to a nominal assessment, i.e., whether a function exists or does not exist without further differentiating the level of fulfillment. The regional forest function plan is a vague legal concept, i.e., local forest agencies are responsible for the correct interpretation and implementation of forest functions (Krott 1985). In Bavaria as the federal state with the largest forest area, the forest administration sets up the forest function plans consisting of maps and explanatory texts. Stakeholders from the forestry sector such as forest owner associations and public agencies such as the nature or water protection agencies have been consulted to identify necessary revisions of the existing plans (StMELF 2015).

Considering the nature of forest function mapping, a comparable ESS assessment would be sufficient if limited to assessing the existence and spatial location of ESS in an expert assessment rather than a numerical quantification. Inherent to the concept, ESS only exist if they contribute to human well-being. To capture this link between ecosystem structures and processes and societal demands, public participation geographic information systems (PPGIS) techniques are commonly used rather than spatially explicit modeling tools for ESS (Brown and Fagerholm 2015). In PPGIS, researchers may elicit local stakeholders' knowledge and preferences. In contrast to forest function mapping with mostly stakeholders from the forest administration (StMELF 2015), a PPGIS approach with stakeholders beyond the forest sector could equally reveal further forest benefits beyond the legally bound or guided forest functions. More heterogeneous stakeholders may reveal different patterns of synergies and trade-offs (King et al. 2015). In contrast to the legally bound forest function, ESS may freely allow (i) participants to identify and partly prioritize ESS; (ii) more diverse stakeholder groups may locate potentially more or different ESS in contrast to forest owners, employees from the forest agencies, or other public agencies; (iii) the ESS concept allows us to look at trade-offs or synergies and gives the freedom for integration or separation of ESS. Contrastingly, the forest function approach should ideally foster the improvement and the integrative provision of multiple forest functions on most sites (Kindler 2016).
In this study, we analyze for the urban forest of Augsburg in southern Germany (i) which different ESS stakeholder groups identify and how different stakeholder groups prioritize ESS. We examine (ii) how the mapped ESS align with forest functions and (iii) which synergies and trade-offs different stakeholder groups identify.

\section{METHODS}

\section{Study area}

The study area was the urban forest in Augsburg in the southwest of the German Federal State of Bavaria (Fig. 1). The studied forest area amounts to 2000 ha (City of Augsburg 2016) and is located very close to the city of Augsburg (286,374 inhabitants [2015; LfStat 2016]). With a total forest area of 7700 ha, Augsburg owns the largest communal forest in Bavaria. The climate is subcontinental (average temperature: $7.5^{\circ} \mathrm{C}$ and average precipitation: $800 \mathrm{~mm}$ ) The study area is entirely designated as nature conservation area (EU Habitats Directive) and more than $80 \%$ as drinking water protection area (Schraudy 2001). It is located along the Lech River. The closeness to the city causes intensive recreational use in the study area.

Fig. 1. Urban forest in Augsburg in southern Germany; the black line delimits the study area.

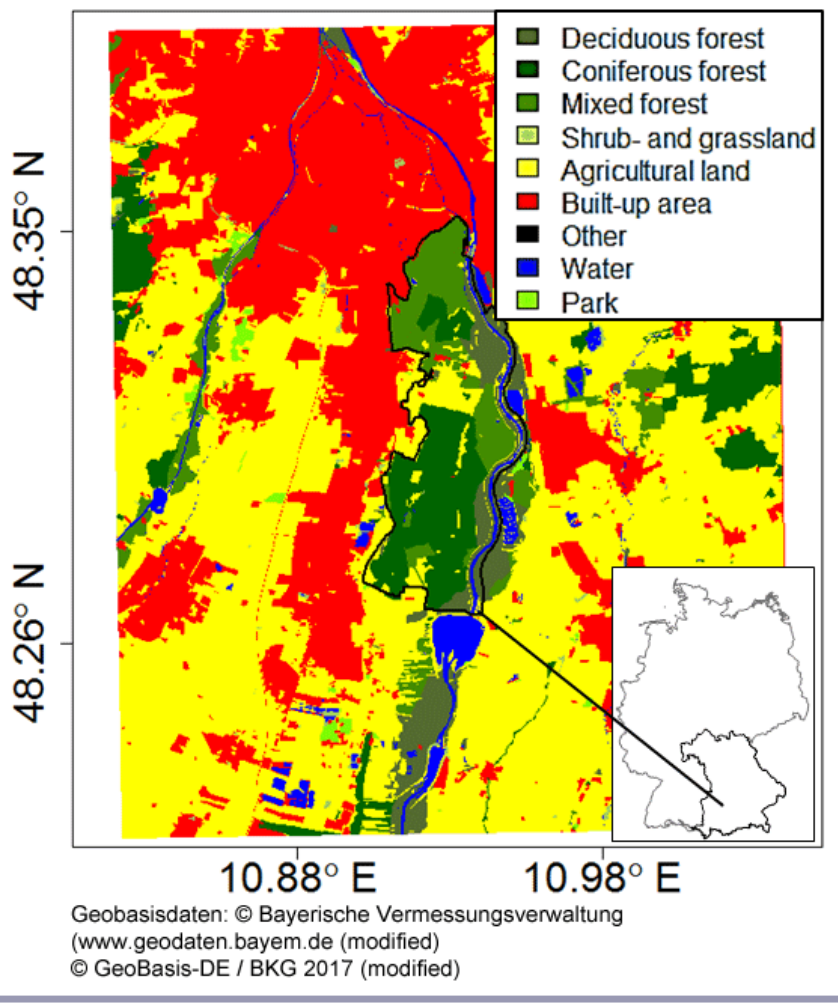

\section{Study design}

\section{Participant recruitment}

We used a stakeholder workshop to map the ESS of the urban forest of Augsburg. We obtained a list of stakeholders both by asking the forest administration and by asking each invited expert for further relevant experts, i.e., a snowball approach as 
recommended by Darvill and Lindo (2015). We used a deliberative approach (Raymond et al. 2014) and defined stakeholders as user groups as well as professional and voluntary actors involved in and affected by forest planning and management. For user groups, we included mainly representatives such as nature conservation or hunting initiatives to obtain more aggregated preferences rather than individual ones. We aimed at experts at the operational level rather than the political level to reduce political interests in the workshop. We identified about 30 stakeholders, of which 22 participated in the workshop. The stakeholders (see Table 1) represented different cultural, regulating, and provisioning services as well as overarching representatives from the forest administration and the department of urban planning of the city of Augsburg. Prior to the workshop, we provided a description (one page) of the concept of ESS and forest functions, and the project aims, which are the identification of ESS and their interactions for the forest of Augsburg. We invited them to represent the preferences of their stakeholder group.

Table 1. Participants by stakeholder group for the urban forest in Augsburg. ESS = ecosystem services.

\begin{tabular}{lllllll}
\hline \hline & \multicolumn{6}{c}{ Table groups } \\
\cline { 2 - 7 } User group & $\mathrm{n}$ & 1 & 2 & 3 & 4 & 5 \\
\hline Forestry & 4 & 1 & 1 & 1 & 1 & \\
Recreation & 4 & 2 & 1 & & & 1 \\
Wood production and use & 1 & & & & & 1 \\
Urban planning & 3 & & & 2 & 1 & \\
$\begin{array}{l}\text { Other ESS (e.g., } \\
\text { mushrooms, honey, game) }\end{array}$ & 3 & 1 & 1 & & 1 & \\
Nature conservation & 5 & & 2 & 1 & 1 & 1 \\
Water protection & 2 & 1 & & & 1 & \\
\hline
\end{tabular}

\section{Workshop design}

The workshop was designed and announced as consultative in terms of gathering information from participants (Reed 2008) and that the results would be shared with the forest administration, but the mandate for changes in forest management would have the forest administration supervised by the city council. We shortly thereafter introduced the aims of the workshop and gave simple examples of agricultural ESS instead of forest ESS to minimize the selection bias of the participants. Biodiversity was announced to be treated as an ESS. We repeated the exercises in five groups to reduce the bias. Each table had at least three different stakeholder groups (see Table 1). We provided each participant with cards and stickers in the color of its stakeholder group as well as a pin board to group the ESS collected in the table groups. In addition, each group had a hardcopy of the topographic map of the forest to map the ESS. We only responded to comprehension questions, but did not comment on the identification and mapping process in the table groups. At the end of the naming and mapping exercise explained in the following section, each group was asked to present its findings in the plenum. The entire mapping workshop took 0.5 day.

\section{Assessment of ecosystem services}

The assessment of ESS was split into three major tasks, which were conducted in five table groups: (i) to identify and group ESS, (ii) to spatially locate ESS, and (iii) to identify synergies and tradeoffs of ESS:

(i) We asked each participant individually to write down at least four relevant ESS for the study area on a card. Together, all participants in a table group thematically grouped their ESS on a pin board. Last, each participant individually could rate his or her preferred ESS on the pin board with a maximum of six stickers. We color-coded both cards and stickers to capture the preferences of the stakeholder groups as listed in Table 1. As entire table group, (ii) we asked the participants to draw their ESS on the topographic map (points, lines, polygons). We emphasized to consider the ESS identified in task (i). (iii) We asked the participants as table groups to identify and classify interactions between ESS. In that respect, the participants created pairs of ESS. The participants classified the interactions, e.g., synergies or trade-offs, and justified their choices.

\section{Evaluation}

Given the manifold wording on the cards denominating the same ESS, e.g., "timber" and "wood," we first had to classify the contents of the cards following Common International Classification of Ecosystem Services (CICES; Haines-Young and Potschin 2013). We used CICES instead of classifications such as the Millennium Ecosystem Assessment (MEA) or The Economics of Ecosystems and Biodiversity (TEEB) initiative. In CICES, the three main categories, provisioning, cultural, and supporting ESS are final, user-demanded services and the supporting ESS in the MEA are rather underlying ecosystem processes and functions (Potschin and Haines-Young 2011). CICES also provides a more detailed, nested hierarchical list of ESS (Lee and Lautenbach 2016) with divisions and classes for facilitated implementation. We attributed mentioned CICES divisions and classes to stakeholder groups (Table 1). We divided the CICES division "nutrition" into "drinking water" and "food" to reveal the mentions of drinking water because the study area is largely designated as a water protection area. Furthermore, we shortened the names of CICES divisions (Table A1.2). In a second step, we evaluated the stakeholder preferences by counting the stickers on the cards and their related ESS divisions and classes. In case of eventually grouped cards with shared stickers, we distributed the stickers proportional to the number of mentions. Thereby, we could relate stakeholder groups (a) to the number of ESS mentions and (b) preferences.

Statistically, we compared (i) the scoring of the stakeholder groups for the respective ESS and (ii) the scoring of ESS without differentiating between stakeholder groups. We conducted MANOVAS and applied a Tukey's range test using the $\mathrm{R}$ statistics package (version 3.3.0; R Development Core Team 2016) following the approach of Hicks et al. (2013). We standardized the values between 0 and 1 and used the square root of scoring values for the comparison of stakeholder groups. For the comparison of overall ESS scorings, we log-transformed the scoring values and multiplied them by the share of cards per ESS division in each table group. The latter corrected for the fact that there may be several cards for one ESS division or class. Without weighting, a frequently listed ESS may be underestimated because of a lower average scoring as the participants have more cards to put their scoring stickers on. To quantify whether the participants rate the ESS divisions in a balanced manner, we calculated the Gini coefficient for both stakeholder groups and ESS. 
Table 2. Differences in ecosystem service scorings between stakeholder groups (MANOVAs and Tukey's range test); ecosystem services (ESS): R(ecreation), B(iodiversity), I(mmission control), D(rinking water), $\mathrm{F}$ (ood), M(ediation of climate and water), T(imber), O (ther), Fu(elwood), Fl(ood protection); Stakeholder groups: R(ecreation), F(orestry), W(ood production), N(ature conservation), O (ther), U(rban planning), Wa(ter protection).

\begin{tabular}{|c|c|c|c|}
\hline ESS & $\mathrm{F}$ & $P$ & Order (ESS) \\
\hline All & $18.69_{117,9}$ & $<0.0001$ & $\begin{array}{l}\mathrm{R}>\mathrm{B}, \mathrm{I}, \mathrm{D}, \mathrm{F}, \mathrm{M}, \mathrm{T}, \mathrm{O}, \mathrm{Fu}, \mathrm{Fl} \\
\mathrm{D}>\mathrm{Fu}, \mathrm{Fl} ; \mathrm{B}, \mathrm{I}>\mathrm{Fl} ; \mathrm{B}>\mathrm{O}\end{array}$ \\
\hline ESS & $\mathrm{F}$ & $\mathrm{P}$ & Order (stakeholder group) \\
\hline Timber & $2.934_{456}$ & 0.0168 & $\mathrm{~W}>\mathrm{R}$ \\
\hline Fuelwood & $1.086_{5,0}^{5,5}$ & 0.4650 & - \\
\hline Food & $4.244_{38,5}^{5,5}$ & 0.0037 & $\mathrm{~F}, \mathrm{~N}, \mathrm{O}>\mathrm{R}$ \\
\hline Drinking water & $0.309_{48,6}^{38,5}$ & 0.9290 & - \\
\hline Mediation of climate and water & $0.368_{67.6}^{48,6}$ & 0.8960 & - \\
\hline Immission control & $0.614_{10,0}^{6,0}$ & 0.6660 & - \\
\hline Flood protection & $1.103_{7,4}^{19,5}$ & 0.4280 & - \\
\hline Recreation & $5.757_{155}^{1,4}$ & $<0.0001$ & $\mathrm{~N}>\mathrm{Wa} ; \mathrm{R}>\mathrm{F}, \mathrm{O}, \mathrm{Wa} ; \mathrm{U}>\mathrm{Wa}$ \\
\hline Biodiversity & $0.858^{155,6}$ & 0.5290 & 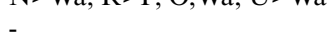 \\
\hline Other & $0.677^{0,6}$ & 0.6460 & - \\
\hline
\end{tabular}

Second, we digitized and analyzed the mapped ESS. Designated forest functions were taken from the revised and approved maps for the region of Augsburg including the study area (StMELF 2013). We calculated the richness of ESS and forest functions respectively. Thereby, we analyzed the results individually per table group and aggregated them for all tables. We compared the outcome with the forest function richness. To identify whether the table group would reliably identify forest functions, we applied diagnostic test statistics for individual table groups and the entire set of mapped ESS. We followed Gos and Lavorel (2012) as they state that an overlap analysis may provide misleading results because it does not consider the size effect. For example, a small ESS area may have a large overlap with a large forest function area although a high agreement is not given. Therefore, we calculated the cross-predictive capacity (Altman and Bland 1994) with two indices with $\mathrm{R}$ statistics package ( $\mathrm{R}$ Development Core Team 2016): sensitivity and specificity (scaled between 0 and 1). A high sensitivity showed a mostly correct categorization of locations of forest functions by ESS mapping. A high specificity showed a mostly correct identification of locations without forest functions and without ESS (Meyer et al. 2016). To identify the informational value for each table group, we combined the different ESS maps of the table groups and tested the agreement with the forest function maps. This may equally give an indication, on the reliability of table groups for ESS mapping.

Third, we evaluated the interactions of ESS and forest functions based on two approaches. (i) We applied a multiple factor analysis for the mapped forest functions and ESS in the R statistics package (version 3.3.0; R Development Core Team 2016). Thereby, we identified overlaps between individual forest functions or ESS and with each other. (ii) We asked the participants to list relevant synergies and trade-offs in the study area to qualify potential overlaps.

\section{RESULTS}

\section{Mentioning and scoring of ecosystem services}

In total, the participants mentioned 127 ESS including repetitions. The mentions matched seven out of eight CICES divisions and 18 out of 49 CICES classes (Table A1.2). Six cards did not name services but land use or infrastructure and could not be attributed at all ("other") and another 26 could be related only to CICES divisions with no differentiation for the CICES class.

Recreation, biodiversity, mediation of climate and water, drinking water, and wood (timber and fuelwood) were the most frequently listed ESS for all stakeholder groups (see Fig. 2a,b). For the scoring of ESS (Fig. 2c,d), equally to the listing of ESS, all participants scored recreation most (39\% of all stickers), which is followed by drinking water (provision) and biodiversity. Flood protection was least prioritized. Statistically (see Table 2), the significant higher scoring of recreation than of most other ESS in Tukey's range test confirmed this pattern. In addition, stakeholders scored flood protection lower than biodiversity, immission control, and drinking water as well as drinking water higher than fuelwood.

The recreation stakeholder group listed their own ESS to the largest share of $56 \%$ of all mentions (Fig. 3). All stakeholders rarely mentioned flood protection and fuelwood. Statistically (see Fig. 3), we confirmed the major patterns of Fig. 2 and Fig. 3. Recreation stakeholders scored recreation higher than forest, other, and water protection stakeholders. Interestingly, nature conservation stakeholders equally scored recreation higher than water protection stakeholders. Vice versa, recreation stakeholders scored food lower than forest, nature conservation, and other stakeholders and timber lower than wood production stakeholders. In sum, recreation stakeholders significantly emphasized their focus ESS in contrast to other stakeholder groups such as forestry or nature conservation stakeholders. Equal weights for all stakeholder groups (Fig. 2b,d) showed mostly patterns comparable to the unweighted listing and scoring (Fig. 2a,c). Only biodiversity was less important (fourth most important forest benefit if weighted [Fig. $2 \mathrm{c}$ vs. Fig. 2d]) and fuelwood would be more important than food production.

In addition, most stakeholder groups if corrected for their absolute number ranked recreation and drinking water comparably equal (Gini coefficient, see Table 3). The emphasis of water protection stakeholders on mediation of climate and water 
Fig. 2. Listing $(a, b)$ and scoring $(c, d)$ of ecosystem services aggregated to common international classification of ecosystem services divisions; $a$ and $\mathrm{c}$ indicate the number of mentions and number of scoring points by the workshop participants, respectively; $b$ and $d$ indicate the sum of percentage points from the relative share or cards or scoring points from each stakeholder group per ecosystem service, i.e., equal weights for each stakeholder group.

(a)

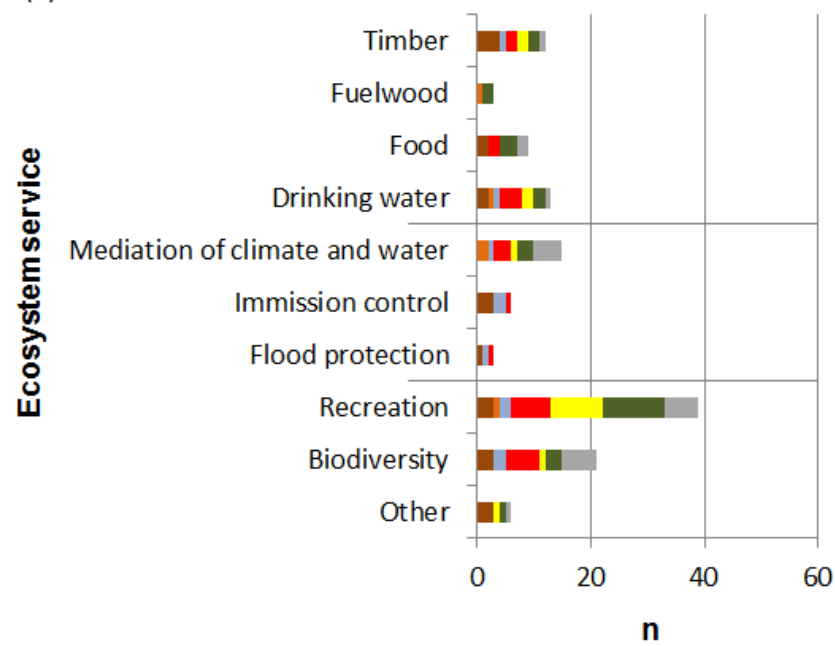

(c)

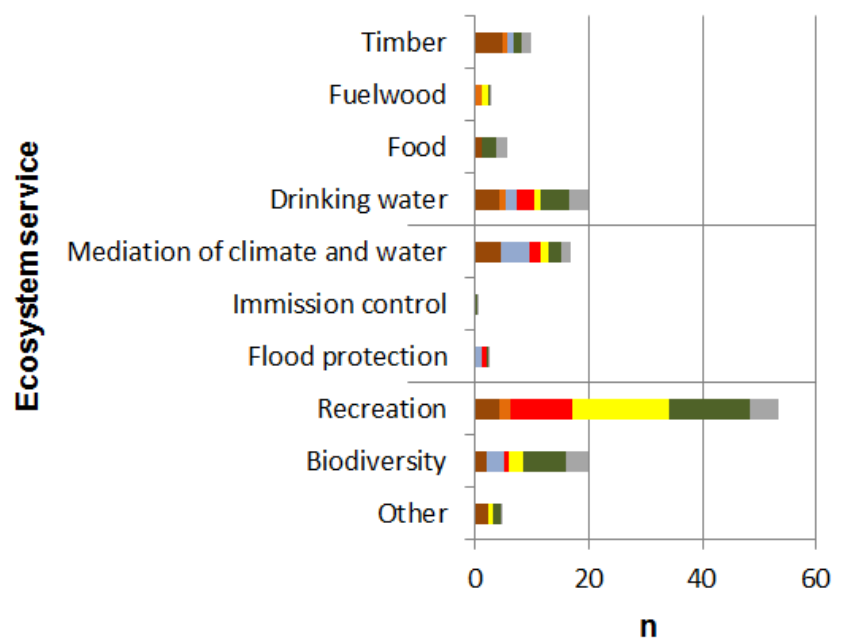

(b)

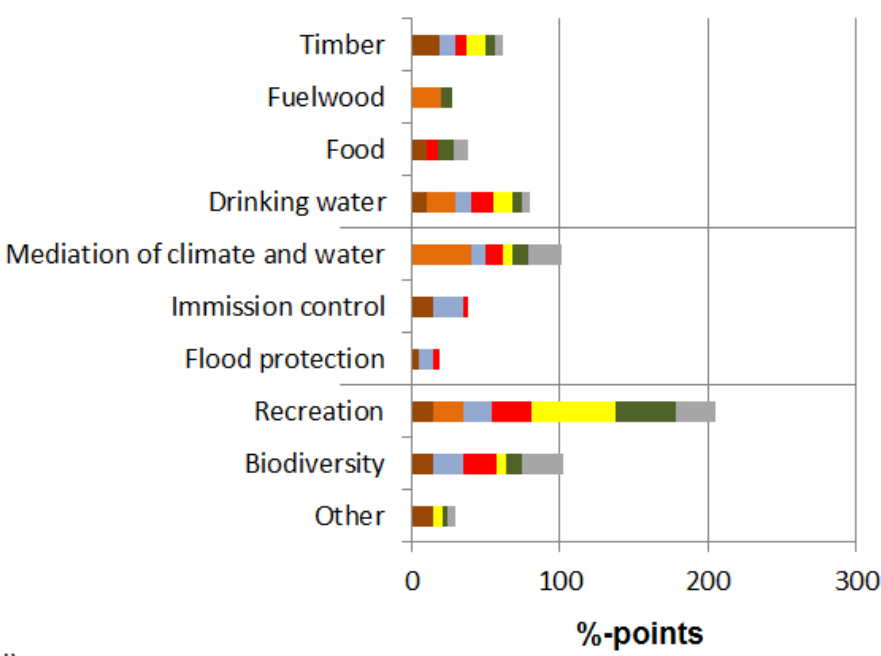

(d)

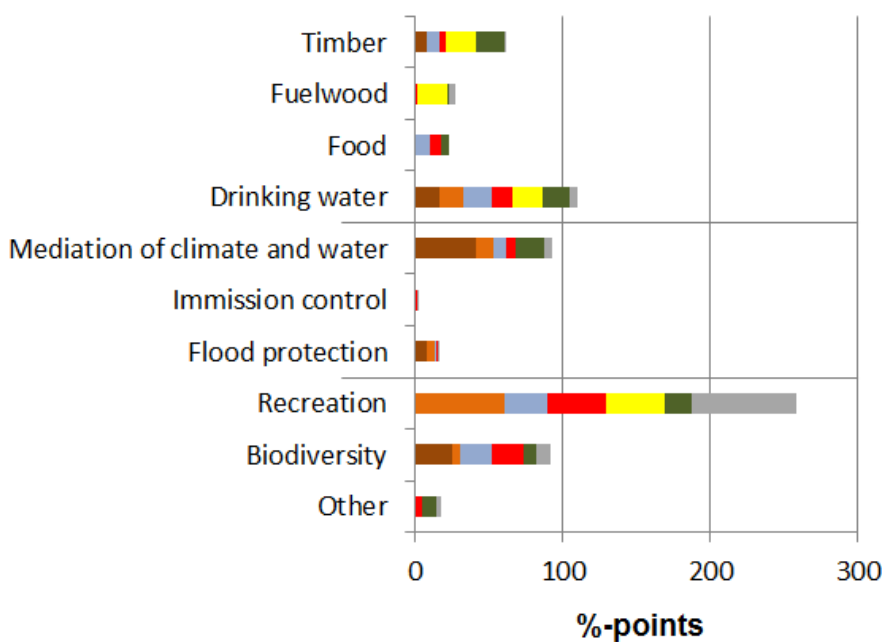

\begin{tabular}{|lc|}
\hline Stakeholder group & Urban planning \\
$\square$ Forestry & Recreation \\
Wood production and use & $\mathbf{v}$ Nature conservation \\
Water protection & Other \\
\hline
\end{tabular}

became apparent as well (Fig. 2d and Fig. 3). Forest stakeholder scored most balanced (G: 0.4748; Table 3 and Fig. 3).

\section{Richness and spatial agreement}

The richness of forest functions and ESS amounted to a maximum of seven and six, respectively (see Fig. 4). Most of the area had four ESS and forest functions, which were nature conservation, recreation, drinking water, and climate regulation. Wood as forest function equally covered the entire forest area. Forest functions combine local climate regulation with immission control. Regarding the patterns of forest functions, we may consider that parts without tree cover in the center of the city forest map (light blue) were not considered as part of the forest in forest function mapping, i.e., climate, noise, and immission regulation, use (wood), as well as the recreational functions. Contrastingly, nature conservation and drinking water areas included this area without tree cover as designated independent from forest land use. Orange areas in the southern part of the forest (Fig. 4) did not have a recreational function. The light green area in the center missed recreational, climate regulation, and immission control functions. For ESS, the light green area for provisioning ESS integrated drinking water, drinking water hotspots, and feed production. 
Fig. 3. Scoring of ecosystem services by stakeholder groups aggregated to common international classification of ecosystem services divisions.

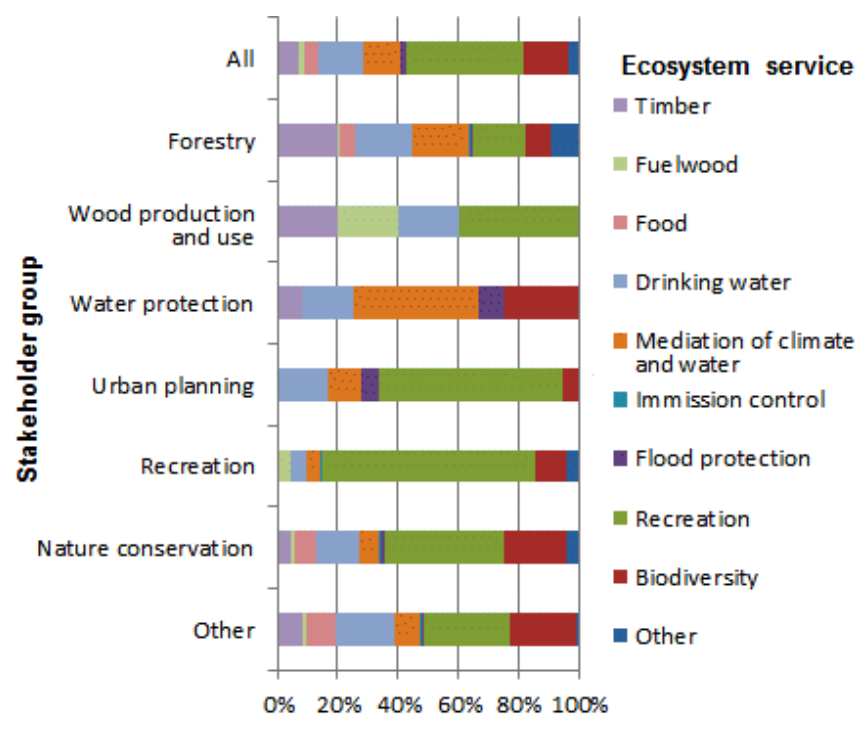

Table 3. Gini coefficients as a measure of rating inequality by stakeholder group and by ecosystem service; 0 indicates equal ratings for all stakeholder groups or ecosystem services; 1 indicates full inequality, i.e., one ecosystem service or stakeholder group receives the entire scoring points.

\begin{tabular}{lclc}
\hline \hline $\begin{array}{l}\text { Stakeholder } \\
\text { group }\end{array}$ & $\begin{array}{c}\text { Gini } \\
\text { coefficient }\end{array}$ & Ecosystem service & $\begin{array}{c}\text { Gini } \\
\text { coefficient }\end{array}$ \\
\hline $\begin{array}{l}\text { Forestry } \\
\begin{array}{l}\text { Wood } \\
\text { production }\end{array}\end{array}$ & 0.4748 & Timber & 0.6111 \\
$\begin{array}{l}\text { Water } \\
\text { protection }\end{array}$ & 0.7333 & Fuelwood & 0.6653 \\
$\begin{array}{l}\text { Urban } \\
\text { planning }\end{array}$ & 0.7407 & Food & 0.7511 \\
$\begin{array}{l}\text { Recreation } \\
\text { Nature }\end{array}$ & 0.8271 & Drinking water & 0.3361 \\
conservation & 0.6530 & Mediation of climate & 0.4871 \\
Other & 0.5780 & $\begin{array}{l}\text { Imd water } \\
\text { Immission control }\end{array}$ & 0.6444 \\
& & $\begin{array}{l}\text { Flood protection } \\
\text { Recreation }\end{array}$ & 0.6761 \\
& & $\begin{array}{l}\text { Biodiversity } \\
\text { Other }\end{array}$ & 0.4385 \\
& & & 0.4952 \\
& & & 0.7802 \\
\hline
\end{tabular}

Major differences between forest functions and ESS were small biodiversity hotspots (light blue, Fig. 4, cultural map). These areas were not part of the forest function map. Contrastingly, recreational forest functions only covered parts of the area (light blue), whereas the entire study area provided recreational ESS (dark green). The maintenance of surface water quality was mapped as regulating ESS in contrast to forest functions.

In addition, we identified how individual forest functions and ESS aligned (see Table A1.1). The high sensitivity of ESS for comparing ESS and forest function mapping (sensitivity equal to one) showed that the combined ESS maps of all table groups (ESS [all]) and ESS table group one (ESS 1) identified all forest function areas. However, the ESS mapping spatially exceeded comparable forest functions. Especially, recreation and climate regulation are not forest functions in the entire study area but in selected parts (positive predictive value [PPV] below one). Apart from ESS 1, the remaining table groups did not map the entire forest function area (sensitivity below one) for most ESS. However, the remaining table groups identified areas without forest function better (higher specificity value). Especially, ESS 1 and ESS 3 often exceeded the forest function area. To visualize how the informational value of table groups adds up, we added their ESS mapping except from ESS1. In that respect, the identification of correctly identified forest functions areas and areas without forest function rose. The higher sensitivity and specificity values of multiple table groups were mostly higher than for single table groups.

\section{Interactions of forest functions and ecosystem services}

Regarding the spatial relevance of interactions (see Fig. 5), the forest functions (drinking water, biodiversity) and the ESS (drinking water, biodiversity, and recreation) mostly overlapped (see Fig. 4). Both mapping approaches located the listed forest functions and ESS on the entire area (see previous section). Furthermore, the following forest functions were also close to this cluster (Fig. 5): wood, climate regulation, and landscape aesthetics as well as recreation. Beyond these functions relevant for large parts of the study area, cultural ESS and hunting (ESS) might spatially interfere. Further, ESS such as feed production and biodiversity hotspots (ESS) were barely related.

Questioning the participants for synergies and trade-offs of ESS provided two main patterns (see Table 4). The participants listed the interaction of timber and biodiversity and of drinking water and biodiversity multiple times both as synergies and trade-offs Main trade-offs were between recreation and timber, food, and drinking water, respectively (multiple listings). Stakeholders often mentioned the management of the forest and the different options and intensity levels of activities, e.g., recreation, as critical factors for synergistic ESS supply.

\section{DISCUSSION}

\section{Identification and prioritization}

Although comparable studies for preferences on forest ESS are barely available, our study aligned with land-use overarching studies such as Martín-López et al. (2012) in Spain. For example, recreation and environmental education (included in recreation in our classification) are more important for urban stakeholders similar to this study. Equally, the low listing and scoring of timber and fuelwood in our study showed that urban stakeholders are rather distant to forest production as a relevant ESS. Nevertheless, fuelwood and timber were mentioned and scored subordinately by nearly all stakeholder groups, indicating a certain acceptance for wood harvesting. In another study in Germany, Finland, and Poland (Hauck et al. 2013), the most relevant ESS partly align with our findings: recreation and tourism is their third most important ESS after agriculture and food, and flood protection. Disregarding agriculture for a forestry study, flood production is not relevant anymore because technical flood protection measures against the Lech River replaced the forest as historical 
Fig. 4. Richness of forest functions maps (upper part) and ecosystem services mapped at the workshop (lower part); the first row indicates the richness without categories and the remaining rows by categories following Common International Classification of Ecosystem Services (Haines-Young and Potschin 2013); the scale bar indicates the number of overlapping forest functions and ecosystem services, respectively; biodiversity is included in the richness of forest functions and excluded in the richness of ecosystem services.

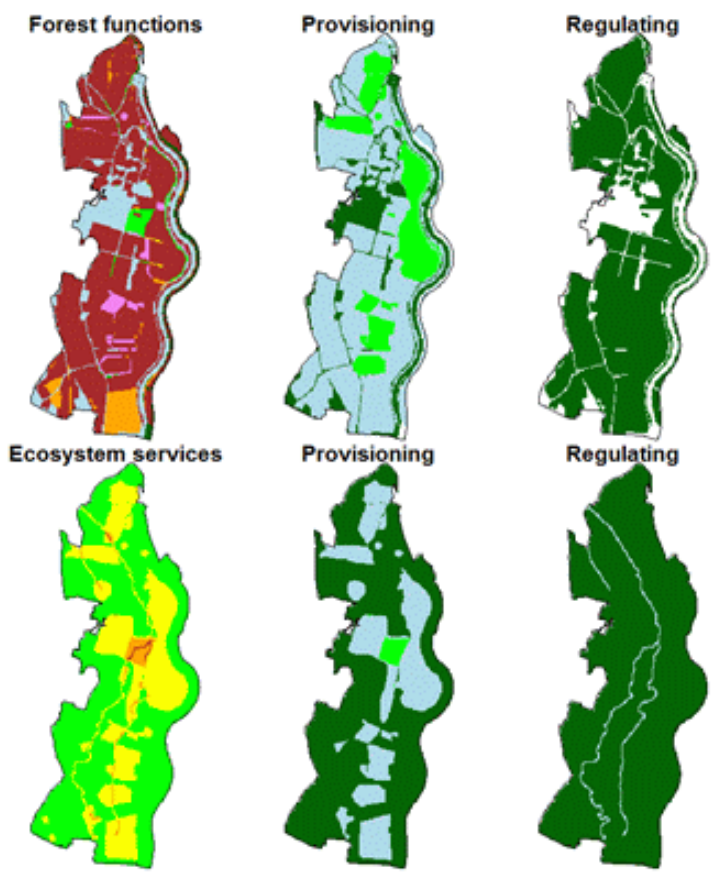

Fig. 5. Scatter plot of the first two dimensions of the factor analysis of the mapped forest functions (FF, blue triangles) and ecosystem services (ESS, red triangles); the spatial coordinates of the forest functions and ecosystem services were supplied as variables for the factor analysis.

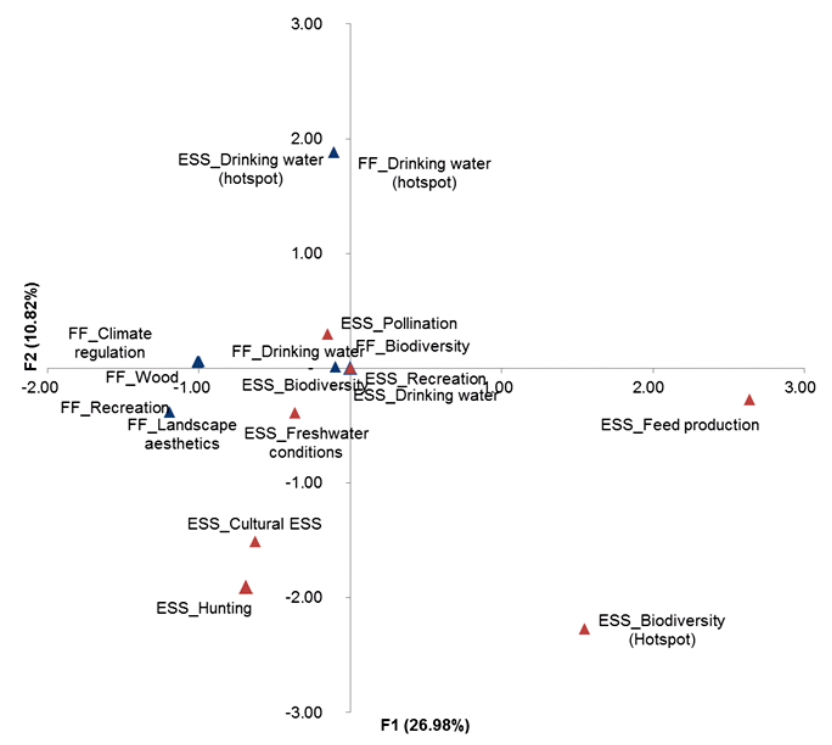

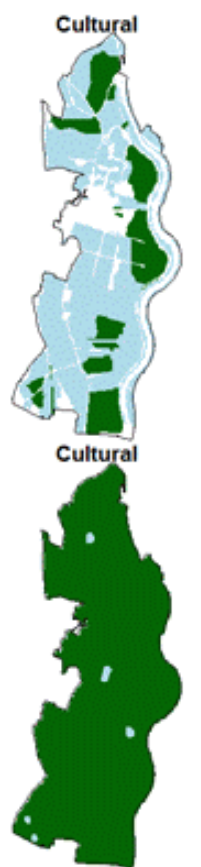

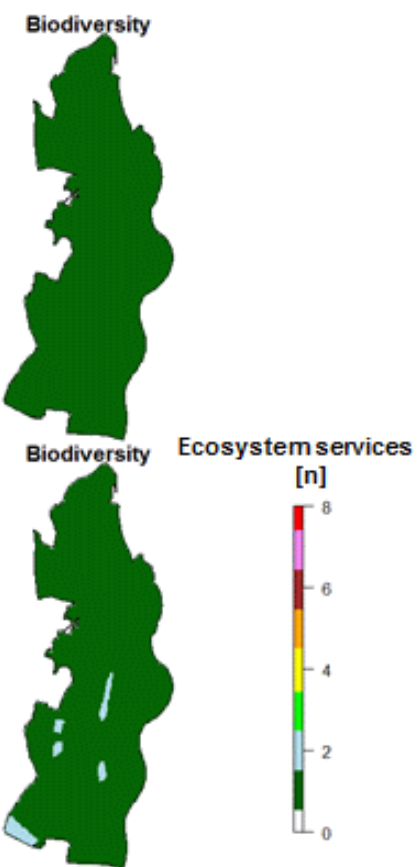

flooding area. The high prioritization of recreation is in line with Crouzat et al. (2016), who assume that stakeholders rate ESS with immediate benefits higher, or with Plieninger et al. (2013a), who identify cultural ESS to be immediately and intuitively appreciated, especially in contrast to provisioning and regulating services. Another trigger for the prioritization of recreation might be the spatial in-situ relationship between supplying and benefiting area (Fisher et al. 2009, Burkhard et al. 2014): recreation is one of few ESS where provision and benefit are realized at the same location.

Previous ESS mapping studies show a low integration of stakeholders in the identification, mapping, and evaluation process (Nahuelhual et al. 2015). We did not opt for a prescriptive list to acquire the ESS that stakeholders actively recall. In addition, we did not want to delimit the number of mentioned ESS because this might demotivate or exclude participants. In that respect, we agree with Pert et al. (2015) to let the participants develop their most relevant ESS. Nevertheless, we grouped the mentioned ESS according to CICES, which was mostly suitable at division level. However, the class level seems less suitable because 26 in 127 mentions would not be attributable to a specific class. Only six mentions were beyond the ESS concept. Therefore, we see CICES as fairly suitable in contrast to Nahuelhual et al. (2016), who fear that different relationships with nature may impede the use of the ESS concept. We only deviated by dividing CICES division "nutrition" in "food" and "drinking water" to respond to the local significance of drinking water (Table A1.2). CICES classes provide a higher diversification but some loss of 
Table 4. Mentions (n) of synergies and trade-offs between ecosystem services by five stakeholder table groups; we listed synergies in the lower left part and trade-offs in the upper right part. The cells on the diagonal may contain synergies (S) and trade-offs (T).

\begin{tabular}{|c|c|c|c|c|c|c|c|c|}
\hline & Timber & Food & $\begin{array}{c}\text { Drinking } \\
\text { water }\end{array}$ & $\begin{array}{c}\text { Flood } \\
\text { protection }\end{array}$ & Recreation & Biodiversity & Other & all \\
\hline Timber & - & - & 2 & - & 3 & 3 & - & - \\
\hline Food & - & $1(\mathrm{~T})$ & 1 & - & 3 & 1 & - & - \\
\hline Drinking water & 1 & - & - & - & 4 & 4 & 1 & - \\
\hline Flood protection & - & - & - & - & - & - & - & - \\
\hline Recreation & - & - & - & - & $1(\mathrm{~S} / \mathrm{T})$ & 2 & - & - \\
\hline Biodiversity & 3 & 1 & 3 & 1 & 1 & - & 1 & - \\
\hline Other & - & - & - & - & 1 & 2 & - & - \\
\hline all & - & - & - & - & 1 & - & - & - \\
\hline
\end{tabular}

information given that some general mentions could only be attributed to CICES divisions. CICES classes lead to less information density, which hampers (statistical) evaluation.

Whether biodiversity is a finite ESS, supports or does not affect ESS provision may vary with the local environmental conditions and social preferences (Mace et al. 2012). Our approach to include biodiversity provided the opportunity for stakeholders to analyze and discuss interactions with ESS. Therefore, we would not argue in favor of a prescriptive list of ESS, but for structuring ESS at the CICES division level for future studies with stakeholders.

The information on the influence of individual stakeholder groups on ESS preferences is essential (García-Nieto et al. 2015). The color-coding of cards and stickers emerged as one approach to analyze stakeholder group behavior and their different priority patterns. The importance of recreation, biodiversity, mediation of climate and water, and drinking water was apparent in the unweighted and equally weighted scoring of ESS and biodiversity (Fig. 2). The weighting showed only slight differences. Fuelwood became more important than food production after equal weighting of stakeholders' scores. In that respect, weighting will be one approach to correct for over- or underrepresentation in a consultative workshop because stakeholders barely participate in a balanced manner.

For a decision-oriented workshop, it is not always reasonable to give equal weights to all stakeholder groups. For the judgment, information on the scoring behavior of different groups is needed (Brown and Kyttä 2014). For example, our results have shown that some stakeholder groups had a stronger preference for one target ESS (recreation, wood production, water protection, urban planning) and others did not (nature conservation, forestry, other) as shown in Fig. 3 and by the Gini coefficients in Table 3. Our findings thereby contradict existing studies (Ananda and Herath 2003), in which all stakeholder groups weighted their target forest benefit significantly higher. This heterogeneous and partly unexpected preference structure makes it difficult to immediately reflect the local population's preferences in stakeholder weighting. Therefore, it might be more reasonable to test how different groups represent the affected population to avoid unintended effects if forest management was changed for modified ESS supply.

\section{Mapping and interactions}

The comparison of regional forest function maps and the stakeholder-based local ESS mapping has shown that a high spatial overlap could be achieved for the most important forest benefits in the study area prioritized by the stakeholder groups: recreation, drinking water, biodiversity, and climate protection (see Table A1.1 and Fig. 4). Forest function mapping and ecosystem services mostly disagreed for selected and less frequently mentioned ESS such as beekeeping or hotspots of cultural ESS. However, some hotspots of landscape aesthetics are roughly mapped as forest functions (StMELF 2013). We did not include these in Fig. 4 because of the missing information on their exact location. The missing actual location might be due to the fact that forest functions have been developed for regional-scale planning and assessment (Bachmann 2005).

The ESS mapping has shown that multiple stakeholder groups are needed to map the entire range and extent of forest functions (see Table A1.1). The spatial agreement of forest functions and ESS and the number of ESS increased with an increasing number of stakeholder groups. Our approach might be one option to evaluate the validity of stakeholder-based ESS mappings as requested by Brown and Fagerholm (2015). Furthermore, it might be interesting to analyze when adding up multiple groups if they overpredict a supply area of ESS, i.e., the entire area could become suitable for an ESS if more stakeholders mapped. The high agreement of forest functions and ESS is also due to the fact that nature and water protection areas have been identified as relevant provisioning areas for forest functions and ESS. Both ESS and forest function mapping designated large parts of the study area as provisioning area for some ESS and forest functions. A deficiency of both approaches is the fact that they do not differentiate for the level of supply and only implicitly consider the demand. For example, forest functions should address the societal demand (Pistorius et al. 2012). Therefore, implications for forest management at stand level would require additional assessments of forest functions or ESS with different levels of supply at a higher spatial resolution.

A main contrast between ESS and forest function mapping is the fact that stakeholders clearly prioritized selected ESS: recreation was prioritized higher than most other functions and flood protection lower (see Table 2). The implementation of forest functions in Bavaria has a rather holistic perspective and requires for the regional scale to maintain the protective and recreational functions, raw material provision and biodiversity (StMELF 2013). In that respect, it is rather the aim to maintain all mapped forest functions. Missing prioritization has advantages and disadvantages. If a forest is managed in favor of diverse ecosystem 
characteristics and dynamics, it will be more likely to ensure resilience (Führer 2000). We thereby assume that it will be more likely suitable for economic, environmental, and societal changes. For example, a more biodiverse forest may ensure a higher longterm productivity for timber (Liang et al. 2016). For current societal demand, missing prioritization (multifunctional forestry) might not completely fulfill single stakeholders' preferences because it is necessary to balance different societal preferences as requested by Gamborg and Larsen (2003). For example, timber production might interfere with biodiversity and recreation as mentioned by the stakeholders (see Table 4). Interestingly, the stakeholders did not map timber as an ESS in the study area, which is in line with the findings in the previous section that immediate benefits are scored higher.

The identified synergies and trade-offs aligned to the spatial interactions, especially for timber and drinking water with recreation and biodiversity, respectively. Furthermore, our findings on synergies and trade-offs agree with Hauck et al. (2013) for important forest ESS. Trade-offs between timber and recreation and mixed synergies and partly trade-offs between drinking water and timber were equally pronounced in their case studies across Europe. Equally to them, we got heterogeneous opinions for the trade-offs and synergies for multiple other ESS. Therefore, especially local-scale studies on ESS should include the management of and demand for ESS to a larger extent.

\section{Transferability}

The forest of Augsburg is an example for an urban forest of a larger city in Europe with high pressure from local recreation needs, which has to be addressed by the local forest management. The recreational benefit of the forest is considered in urban planning. The rather high number of beneficiaries in close proximity to the forest is characteristic for many other urban forests although the overall share of urban forests is rather small in general (Konijnendijk 2003). Other ESS not occurring onsite such as local climate regulation or immission reduction might strongly differ depending on the scale, structure, and the context (Escobedo et al. 2011) such as the location within the city, the overall amount or the form of the urban forest or the temperature levels (Jaganmohan et al. 2015).

Generally, the trade-offs for the case study seemed relatively low. The high appreciation of many ESS might be related to a longlasting local history concerning water protection. The first land purchases by the city of Augsburg for water provision purposes date back to 1818 (Loderer 1986); a legally designated water protection area dominated by forest was established in 1979. In addition, nature protection areas were designated in 1940 and 1942 and the maintenance of the forest area is legally required since 1986. Thus, minor conflicts between stakeholders about ESS may partly reflect the legally manifested societal demands, which may have infiltrated and changed the local foresters' efforts toward adapted management (Ammer and Püttmann 2009). Additionally, the different stakeholders had a long period to become aware of the diversity and significance of local ESS and started "to appreciate the legitimacy of each other's views" (Reed 2008:2420).

Caveats for the transferability are (i) that a rather low level of conflict and a high level of trust between stakeholders cannot be expected in other places. The high level of trust and understanding between the participants and the accepted coexistence of ESS facilitated the mapping process. Other study areas would require a more comprehensive stakeholder analysis to identify conflicts potentially disturbing the mapping process in advance (Reed et al. 2009). (ii) The access to participants for a deliberative process (Raymond et al. 2014) might be more difficult as well. To capture the important interests and benefits from forests might decrease with a decline in the degree of organization in visible initiatives, e.g., nature conservation or sport clubs.

\section{CONCLUSIONS}

The prioritization of ESS has shown a clear trend across most stakeholder groups revealing recreation as major ESS. Only few ESS have been overweighted by stakeholder groups, especially recreation by recreation stakeholders. The immediacy in perception of cultural ESS (Plieninger et al. 2013a) might have created this even if other ESS, especially drinking water provision, are supposed to be of similar if not higher importance for local human well-being. Interestingly, participants simultaneously formulated trade-offs between recreation and drinking water provision indicating that prioritized recreation cannot simply overrule drinking water provision. To avoid such dominance of intuitively appreciated ESS over less obvious, more knowledge dependent ESS, it seems recommendable to introduce techniques that base the prioritization of ESS on an initial learning process of the stakeholders (Reed 2008, Brown and Kyttä 2014).

Forest stakeholders weighted most ESS equally. This is in line with the approach of multifunctional forestry (Schmithüsen 2007) and reflects its establishment especially in an urban area with multiple demands. Their balanced ESS scoring indicates a general awareness of multiple demands. Long-lasting local legal protection areas for drinking water, nature conservation, and forest area maintenance may have fostered local acceptance and adaption of forest stakeholders to this societal demand. However, local adaptive forest management decisions have to assess and moderate local and regional stakeholders' preferences, mapped forest functions, legal constraints (e.g., nature protection areas), and owner interests, in our case, the city, and executed by the city council (Schmithüsen 2007). The clear preferences for selected ESS shown in our study indicate the need for adaptive forest management strategies that balance and satisfy local demand. To support this, stakeholders could be consulted to a larger extent to capture the heterogeneity in preferences explicitly instead of an implicit consideration in forest functions without comprehensive consultation. From a governance perspective, the question might be whether a flexible ESS approach is more suitable than the well-established forest function mapping. Nevertheless, most forest functions fit into CICES. More explicitly, future research should show (i) how and at which spatial scale priority patterns of different stakeholder groups align with current forest management and (ii) if exemplary mapping and assessing of ESS at local scales and their interaction with silvicultural management can help to demonstrate the effects of potential influences on the bundles of ESS. Data-based mapping of local ESS and the discussion of corresponding silvicultural solutions might help to visualize and clarify the link between forest management and local demand. For forestry, there are numerous studies on the impact of forest management on few ESS, especially timber, carbon sequestration, and biodiversity such as van der Plas et al. (2016). Few also include regulating ESS 
and model them in a spatially explicit manner (Meyer et al. 2015). The explaining factors of bundles of provisioning, regulating, and cultural ESS are often assessed at the regional scale, e.g., GarcíaNieto et al. (2013), Qiu and Turner (2013), or Raudsepp-Hearne et al. (2010), but studies on the local scale barely exist.

Regarding forest function or ESS interactions, existing regional forest function maps generally overlapped with the ESS maps generated at the workshop besides some additional ESS hotspots. However, ESS mapping with higher spatial scrutiny may differ from forest functions possibly leading to clear trade-offs, and may raise the need for decisions for and against single ESS. In the end, a deviation from the multifunctionality paradigm at single forest stand level might be suitable in selected cases (Wagner 2004, Ammer and Püttmann 2009). This is in line with Hauck et al. (2013), who also identified the problem of simplifying or hiding the heterogeneity in synergies and trade-offs at larger scales. Even at the local scale, the stakeholders recognized that the existence of synergies or trade-offs may depend on the actual management, e.g., silvicultural management or urban planning, which has been shown for regulating and provisioning ESS (Duncker et al. 2012). However, in contrast to existing studies in forestry on abstract forest entities (Biber et al. 2015), the spatial link should be considered to set the supply of forest functions or ESS into the context of local demand. One approach could be scenario development as in existing landscape-scale studies (Plieninger et al. 2013b). Here, a challenge will be to translate storylines of scenarios to actual changes in ESS (Priess and Hauck 2014), especially at the local scale. The applied mapping approach should be transferable to most urban forests in Europe; the comparison between ESS and forest functions might not only be limited to countries with the forest function concept, but could be done with other forest planning and prioritization instruments, which are used to satisfy multiple-use forestry worldwide (McArdle 1953, García-Fernández et al. 2008).

Responses to this article can be read online at: http://www.ecologyandsociety.org/issues/responses. $\mathrm{php} / 9372$

\section{Acknowledgments:}

This work was partly funded by the Foundation for Forest Research in Bavaria. The authors thank the forest administration of the city of Augsburg for their support and thank all workshop participants for their valuable input. Furthermore, the authors would like to thank Ulrich Stetter for valuable input on forest functions.

\section{LITERATURE CITED}

Altman, D. G., and J. M. Bland. 1994. Statistics notes: diagnostic tests 1: sensitivity and specificity. British Medical Journal 308 (6943):1552. http://dx.doi.org/10.1136/bmj.308.6943.1552

Ammer, C., and K. Püttmann. 2009. Waldbau, quo vadis? Waldbewirtschaftung zwischen Funktionenorientierung und Multifunktionalität. Forstarchiv 80(3):90-96.

Ananda, J., and G. Herath. 2003. The use of analytic hierarchy process to incorporate stakeholder preferences into regional forest planning. Forest Policy and Economics 5(1):13-26. http:// dx.doi.org/10.1016/s1389-9341(02)00043-6

Bachmann, P. 2005. Forstliche Planung - heute und morgen | Forestry planning: today and tomorrow. Schweizerische Zeitschrift für Forstwesen 156(5):137-141. http://dx.doi. org/10.3188/szf.2005.0137

Biber, P., J. Borges, R. Moshammer, S. Barreiro, B. Botequim, Y. Brodrechtová, V. Brukas, G. Chirici, R. Cordero-Debets, E. Corrigan, L. Eriksson, M. Favero, E. Galev, J. Garcia-Gonzalo, G. Hengeveld, M. Kavaliauskas, M. Marchetti, S. Marques, G. Mozgeris, R. Navrátil, M. Nieuwenhuis, C. Orazio, I. Paligorov, D. Pettenella, R. Sedmák, R. Smreček, A. Stanislovaitis, M. Tomé, R. Trubins, J. Tuček, M. Vizzarri, I. Wallin, H. Pretzsch, and O. Sallnäs. 2015. How sensitive are ecosystem services in European forest landscapes to silvicultural treatment? Forests 6 (5):1666-1695. http://dx.doi.org/10.3390/f6051666

Brown, G., and N. Fagerholm. 2015. Empirical PPGIS/PGIS mapping of ecosystem services: a review and evaluation. Ecosystem Services 13:119-133. http://dx.doi.org/10.1016/j. ecoser.2014.10.007

Brown, G., and M. Kyttä. 2014. Key issues and research priorities for public participation GIS (PPGIS): a synthesis based on empirical research. Applied Geography 46:122-136. http://dx.doi. org/10.1016/j.apgeog.2013.11.004

Bürger-Arndt, R. 2013. Waldfunktionen und Ökosystemleistungen im wissenschaftlichen Diskurs. Pages 24-30 in I. Ring, editor. Wälder: Dritte Veranstaltung der Workshop-Reihe des Bundesamtes für Naturschutz ... 24. - 27. September 2012, Internationale Naturschutzakademie Insel Vilm. Bundesamt für Naturschutz, Bonn, Germany.

Bürger-Arndt, R., B. Ohse, K. Meyer, and A. Höltermann, editors. 2012. Ökosystemdienstleistungen von Wäldern: Workshopbericht Internationale Naturschutzakademie Insel Vilm 16. - 19. November 2011. Bundesamt für Naturschutz (BfN), Bonn-Bad Godesberg, Germany.

Burkhard, B., M. Kandziora, Y. Hou, and F. Müller. 2014. Ecosystem service potentials, flows and demands - concepts for spatial localisation, indication and quantification. Landscape Online 34:1-32. http://dx.doi.org/10.3097/10.201434

City of Augsburg. 2016. Stadtwald Augsburg - Erholung rund um Lech und Wertach. City of Augsburg, Germany. [online] URL: http://www.augsburg.de/freizeit/ausflugsziele/stadtwald/

Crouzat, E., B. Martín-López, F. Turkelboom, and S. Lavorel. 2016. Disentangling trade-offs and synergies around ecosystem services with the influence network framework: illustration from a consultative process over the French Alps. Ecology and Society 21(2):32. http://dx.doi.org/10.5751/es-08494-210232

Darvill, R., and Z. Lindo. 2015. Quantifying and mapping ecosystem service use across stakeholder groups: implications for conservation with priorities for cultural values. Ecosystem Services 13:153-161. http://dx.doi.org/10.1016/j.ecoser.2014.10.004

Duncker, P. S., K. Raulund-Rasmussen, P. Gundersen, K. Katzensteiner, J. de Jong, H. P. Ravn, M. Smith, O. Eckmüllner, and H. Spiecker. 2012. How forest management affects ecosystem 
services, including timber production and economic return: synergies and trade-offs. Ecology and Society 17(4):50. http://dx. doi.org/10.5751/es-05066-170450

Escobedo, F. J., T. Kroeger, and J. E. Wagner. 2011. Urban forests and pollution mitigation: analyzing ecosystem services and disservices. Environmental Pollution 159(8-9):2078-2087. http:// dx.doi.org/10.1016/j.envpol.2011.01.010

Fisher, B., R. K. Turner, and P. Morling. 2009. Defining and classifying ecosystem services for decision making. Ecological Economics 68(3):643-653. http://dx.doi.org/10.1016/j. ecolecon.2008.09.014

Führer, E. 2000. Forest functions, ecosystem stability and management. Forest Ecology and Management 132(1):29-38. http://dx.doi.org/10.1016/s0378-1127(00)00377-7

Gamborg, C., and J. B. Larsen. 2003. 'Back to nature'-a sustainable future for forestry? Forest Ecology and Management 179(1-3):559-571. https://doi.org/10.1016/S0378-1127(02)00553-4

García-Fernández, C., M. Ruiz-Pérez, and S. Wunder. 2008. Is multiple-use forest management widely implementable in the tropics? Forest Ecology and Management 256(7):1468-1476. https://doi.org/10.1016/j.foreco.2008.04.029

García-Nieto, A. P., M. García-Llorente, I. Iniesta-Arandia, and B. Martín-López. 2013. Mapping forest ecosystem services: from providing units to beneficiaries. Ecosystem Services 4:126-138. http://dx.doi.org/10.1016/j.ecoser.2013.03.003

García-Nieto, A. P., C. Quintas-Soriano, M. García-Llorente, I. Palomo, C. Montes, and B. Martín-López. 2015. Collaborative mapping of ecosystem services: the role of stakeholders' profiles. Ecosystem Services 13:141-152. http://dx.doi.org/10.1016/j. ecoser.2014.11.006

Gos, P., and S. Lavorel. 2012. Stakeholders' expectations on ecosystem services affect the assessment of ecosystem services hotspots and their congruence with biodiversity. International Journal of Biodiversity Science, Ecosystem Services \& Management 8(1-2):93-106. http://dx.doi.org/10.1080/21513732.2011 .646303

Grêt-Regamey, A., S. H. Brunner, J. Altwegg, M. Christen, and P. Bebi. 2013. Integrating expert knowledge into mapping ecosystem services trade-offs for sustainable forest management. Ecology and Society 18(3):34. http://dx.doi.org/10.5751/ es-05800-180334

Haase, D., N. Larondelle, E. Andersson, M. Artmann, S. Borgström, J. Breuste, E. Gomez-Baggethun, A. Gren, Z. Hamstead, R. Hansen, N. Kabisch, P. Kremer, J. Langemeyer, E. L. Rall, T. McPhearson, S. Pauleit, S. Qureshi, N. Schwarz, A. Voigt, D. Wurster, and T. Elmqvist. 2014. A quantitative review of urban ecosystem service assessments: concepts, models, and implementation. Ambio 43(4):413-433. http://dx.doi.org/10.1007/ s13280-014-0504-0

Haines-Young, R., and M. Potschin. 2013. Common international classification of ecosystem services (CICES): consultation on Version 4, August - December 2012. Report to the European Environment Agency, Copenhagen, Denmark.

Hauck, J., C. Görg, R. Varjopuro, O. Ratamäki, and K. Jax. 2013. Benefits and limitations of the ecosystem services concept in environmental policy and decision making: some stakeholder perspectives. Environmental Science \& Policy 25:13-21. http://dx. doi.org/10.1016/j.envsci.2012.08.001

Hicks, C. C., N. A. J. Graham, and J. E. Cinner. 2013. Synergies and tradeoffs in how managers, scientists, and fishers value coral reef ecosystem services. Global Environmental Change 23 (6):1444-1453. http://dx.doi.org/10.1016/j.gloenvcha.2013.07.028

Jaganmohan, M., S. Knapp, C. M. Buchmann, and N. Schwarz. 2015. The bigger, the better? The influence of urban green space design on cooling effects for residential areas. Journal of Environmental Quality 45(1):134-145. http://dx.doi.org/10.2134/ jeq2015.01.0062

Kindler, E. 2016. A comparison of the concepts: ecosystem services and forest functions to improve interdisciplinary exchange. Forest Policy and Economics 67:52-59. http://dx.doi. org/10.1016/j.forpol.2016.03.011

King, E., J. Cavender-Bares, P. Balvanera, T. H. Mwampamba, and S. Polasky. 2015. Trade-offs in ecosystem services and varying stakeholder preferences: evaluating conflicts, obstacles, and opportunities. Ecology and Society 20(3):25. http://dx.doi. org/10.5751/es-07822-200325

Konijnendijk, C. C. 2003. A decade of urban forestry in Europe. Forest Policy and Economics 5(2):173-186. http://dx.doi. org/10.1016/s1389-9341(03)00023-6

Krott, M. 1985. Zu den Waldfunktionen als Instrument der forstpolitischen Wissenschaft und Praxis. Centralblatt für das gesamte Forstwesen 102(1):1-28.

Lee, H., and S. Lautenbach. 2016. A quantitative review of relationships between ecosystem services. Ecological Indicators 66:340-351. http://dx.doi.org/10.1016/j.ecolind.2016.02.004

LfStat (Bavarian State Office for Statistics). 2016. Bevölkerung: Kreise, Geschlecht, Nationalität, Stichtag (12411-005r). [online] URL: https://www.statistikdaten.bayern.de/genesis/online?language= $\underline{\text { de\&sequenz }=\text { TabelleErgebnis \&selectionname }=12411-005 \mathrm{r}}$

Liang, J., T. W. Crowther, N. Picard, S. Wiser, M. Zhou, G. Alberti, E.-D. Schulze, A. D. McGuire, F. Bozzato, H. Pretzsch, S. deMiguel, A. Paquette, B. Herault, M. Scherer-Lorenzen, C. B. Barrett, H. B. Glick, G. M. Hengeveld, G.-J. Nabuurs, S. Pfautsch, H. Viana, A. C. Vibrans, C. Ammer, P. Schall, D. Verbyla, N. Tchebakova, M. Fischer, J. V. Watson, H. Y. H. Chen, X. Lei, M.J. Schelhaas, H. Lu, D. Gianelle, E. I. Parfenova, C. Salas, E. Lee, B. Lee, H. S. Kim, H. Bruelheide, D. A. Coomes, D. Piotto, T. Sunderland, B. Schmid, S. Gourlet-Fleury, B. Sonke, R. Tavani, J. Zhu, S. Brandl, J. Vayreda, F. Kitahara, E. B. Searle, V. J. Neldner, M. R. Ngugi, C. Baraloto, L. Frizzera, R. Balazy, J. Oleksyn, T. Zawila-Niedzwiecki, O. Bouriaud, F. Bussotti, L. Finer, B. Jaroszewicz, T. Jucker, F. Valladares, A. M. Jagodzinski, P. L. Peri, C. Gonmadje, W. Marthy, T. O'Brien, E. H. Martin, A. R. Marshall, F. Rovero, R. Bitariho, P. A. Niklaus, P. AlvarezLoayza, N. Chamuya, R. Valencia, F. Mortier, V. Wortel, N. L. Engone-Obiang, L. V. Ferreira, D. E. Odeke, R. M. Vasquez, S. L. Lewis, and P. B. Reich. 2016. Positive biodiversity-productivity relationship predominant in global forests. Science 354(6309). http://dx.doi.org/10.1126/science.aaf8957

Loderer, A. A. 1986. Die Besitzgeschichte und Besitzverwaltung der Augsburger Stadtwaldungen: Ein Beitrag zur Augsburger Stadtgeschichte. Dissertation. LMU, München, Germany. 
Mace, G. M., K. Norris, and A. H. Fitter. 2012. Biodiversity and ecosystem services: a multilayered relationship. Trends in Ecology \& Evolution 27(1):19-26. http://dx.doi.org/10.1016/j.tree.2011.08.006

Malinga, R., L. J. Gordon, G. Jewitt, and R. Lindborg. 2015. Mapping ecosystem services across scales and continents - a review. Ecosystem Services 13:57-63. http://dx.doi.org/10.1016/j. ecoser.2015.01.006

Martín-López, B., I. Iniesta-Arandia, M. García-Llorente, I. Palomo, I. Casado-Arzuaga, D. García Del Amo, E. GómezBaggethun, E. Oteros-Rozas, I. Palacios-Agundez, B. Willaarts, J. A. González, F. Santos-Martín, M. Onaindia, C. LópezSantiago, and C. Montes. 2012. Uncovering ecosystem service bundles through social preferences. PLoS ONE 7(6):e38970. http://dx.doi.org/10.1371/journal.pone.0038970

McArdle, R. E. 1953. Multiple use - multiple benefits. Journal of Forestry 51:323-325.

Meyer, M. A., T. Chand, and J. A. Priess. 2015. Comparing bioenergy production sites in the Southeastern US regarding ecosystem service supply and demand. PLoS ONE 10(3): e0116336. http://dx.doi.org/10.1371/journal.pone.0116336

Meyer, M. A., R. Seppelt, F. Witing, and J. A. Priess. 2016. Making environmental assessments of biomass production systems comparable worldwide. Environmental Research Letters 11 (3):34005. http://dx.doi.org/10.1088/1748-9326/11/3/034005

Millennium Ecosystem Assessment (MEA). 2005. Ecosystems and human well-being: current state and trends. R. Hassan, R. Scholes, and N. Ash, editors. Island Press, Washington, D.C., USA.

Nahuelhual, L., F. Benra Ochoa, F. Rojas, G. Ignacio Díaz, and A. Carmona. 2016. Mapping social values of ecosystem services: What is behind the map? Ecology and Society 21(3):24. http://dx. doi.org/10.5751/ES-08676-210324

Nahuelhual, L., P. Laterra, S. Villarino, M. Mastrángelo, A. Carmona, A. Jaramillo, P. Barral, and N. Burgos. 2015. Mapping of ecosystem services: missing links between purposes and procedures. Ecosystem Services 13:162-172. http://dx.doi. org/10.1016/j.ecoser.2015.03.005

Pert, P. L., R. Hill, K. Maclean, A. Dale, P. Rist, J. Schmider, L. Talbot, and L. Tawake. 2015. Mapping cultural ecosystem services with rainforest aboriginal peoples: integrating biocultural diversity, governance and social variation. Ecosystem Services 13:41-56. http://dx.doi.org/10.1016/j.ecoser.2014.10.012

Pistorius, T., H. Schaich, G. Winkel, T. Plieninger, C. Bieling, W. Konold, and K.-R. Volz. 2012. Lessons for REDDplus: a comparative analysis of the German discourse on forest functions and the global ecosystem services debate. Forest Policy and Economics 18:4-12. http://dx.doi.org/10.1016/j.forpol.2011.09.001

Plieninger, T., C. Bieling, B. Ohnesorge, H. Schaich, C. Schleyer, and F. Wolff. 2013b. Exploring futures of ecosystem services in cultural landscapes through participatory scenario development in the Swabian Alb, Germany. Ecology and Society 18(3):39. http://dx.doi.org/10.5751/ES-05802-180339

Plieninger, T., S. Dijks, E. Oteros-Rozas, and C. Bieling. $2013 a$. Assessing, mapping, and quantifying cultural ecosystem services at community level. Land Use Policy 33:118-129. http://dx.doi. org/10.1016/j.landusepol.2012.12.013

Potschin, M. B., and R. H. Haines-Young. 2011. Ecosystem services: exploring a geographical perspective. Progress in Physical Geography 35(5):575-594. http://dx.doi. org/10.1177/0309133311423172

Priess, J. A., and J. Hauck. 2014. Integrative scenario development. Ecology and Society 19(1):12. http://dx.doi. org/10.5751/es-06168-190112

Qiu, J., and M. G. Turner. 2013. Spatial interactions among ecosystem services in an urbanizing agricultural watershed. Proceedings of the National Academy of Sciences of the United States of America 110(29):12149-12154. http://dx.doi.org/10.1073/ pnas. 1310539110

R Development Core Team. 2016. R: a language and environment for statistical computing. The R Project for Statistical Computing, Vienna, Austria. [online] URL: http://r-project.org/.

Raudsepp-Hearne, C., G. D. Peterson, and E. M. Bennett. 2010. Ecosystem service bundles for analyzing tradeoffs in diverse landscapes. Proceedings of the National Academy of Sciences of the United States of America 107(11):5242-5247. http://dx.doi. org/10.1073/pnas.0907284107

Raymond, C. M., J. O. Kenter, T. Plieninger, N. J. Turner, and K. A. Alexander. 2014. Comparing instrumental and deliberative paradigms underpinning the assessment of social values for cultural ecosystem services. Ecological Economics 107:145-156. http://dx.doi.org/10.1016/j.ecolecon.2014.07.033

Reed, M. S. 2008. Stakeholder participation for environmental management: a literature review. Biological Conservation 141 (10):2417-2431. http://dx.doi.org/10.1016/j.biocon.2008.07.014

Reed, M. S., A. Graves, N. Dandy, H. Posthumus, K. Hubacek, J. Morris, C. Prell, C. H. Quinn, and L. C. Stringer. 2009. Who's in and why? A typology of stakeholder analysis methods for natural resource management. Journal of Environmental Management 90(5):1933-1949. http://dx.doi.org/10.1016/j. jenvman.2009.01.001

Schmithüsen, F. 2007. Multifunctional forestry practices as a land use strategy to meet increasing private and public demands in modern societies. Journal of Forest Science 53(6):290-298.

Schraudy, M. 2001. Forstwirtschaftsplan für den Stadtwald Augsburg: Betriebsklasse Auwald. Forest Administration of Augsburg, Augsburg, Germany.

StMELF (Bavarian State Ministry of Food, Agriculture and Forestry). 2013. Waldfunktionsplan für die Region Augsburg, München. [online] URL: http://www.stmelf.bayern.de/wald/ waldfunktionen/waldfunktionsplanung/054599/index.php

StMELF (Bavarian State Ministry of Food, Agriculture and Forestry). 2015. Arbeitsanweisung für die Aktualisierung der Waldfunktionspläne, München.

van der Plas, F., P. Manning, E. Allan, M. Scherer-Lorenzen, K. Verheyen, C. Wirth, M. A. Zavala, A. Hector, E. Ampoorter, L. Baeten, L. Barbaro, J. Bauhus, R. Benavides, A. Benneter, F. Berthold, D. Bonal, O. Bouriaud, H. Bruelheide, F. Bussotti, M. 
Carnol, B. Castagneyrol, Y. Charbonnier, D. Coomes, A. Coppi, C. C. Bastias, S. Muhie Dawud, H. de Wandeler, T. Domisch, L. Finér, A. Gessler, A. Granier, C. Grossiord, V. Guyot, S. Hättenschwiler, H. Jactel, B. Jaroszewicz, F.-X. Joly, T. Jucker, J. Koricheva, H. Milligan, S. Müller, B. Muys, D. Nguyen, M. Pollastrini, K. Raulund-Rasmussen, F. Selvi, J. Stenlid, F. Valladares, L. Vesterdal, D. Zielínski, and M. Fischer. 2016. Jackof-all-trades effects drive biodiversity-ecosystem multifunctionality relationships in European forests. Nature communications 7:11109. http://dx.doi.org/10.1038/ncomms11109

Wagner, S. 2004. Möglichkeiten und Beschränkungen eines funktionsorientierten Waldbaus. Potentialities and Restrictions in Silviculture when Segregating Forest Functions on Stand Level. Forst und Holz(59):105-111.

Wirth, K., M. Wurster, and T. Waldenspuhl. 2015. Leitfaden zur Kartierung der Schutz- und Erholungsfunktion des Waldes: Waldfunktionenkartierung (WFK). Forest Research Institute of Baden-Württemberg, Freiburg, Germany.

Wong, C. P., B. Jiang, A. P. Kinzig, K. N. Lee, and Z. Ouyang. 2015. Linking ecosystem characteristics to final ecosystem services for public policy. Ecology letters 18(1):108-118. http://dx. doi.org/10.1111/ele.12389 
Appendix 1: Statistical agreement between forest function and ecosystem service maps (Table A1.1.) and mentioned CICES divisions of ecosystem services and corresponding forest functions (Table A1.2.)

Table A1.1. Agreement of forest functions and ecosystem services maps; true positive (TP), true negative (TN), false positive (FP), positive predictive value (PPV), negative predictive value (NPV); sensitivity (agreement of pixels classified as ESS or forest function) and specificity (agreement of pixels not classified as ESS or forest function) are scaled between 0 and 1 . If an ESS/forest function is not indicated, it will not have been mentioned by the table group.

\begin{tabular}{|c|c|c|c|c|c|c|c|c|c|}
\hline Combinations & ESS/forest functions & TP & TN & FP & FN & PPV & NPV & Sensitivity & Specificity \\
\hline \multicolumn{10}{|l|}{ ESS (all)/forest } \\
\hline \multirow[t]{5}{*}{ functions } & Biodiversity & 24,204 & 0 & 4 & 0 & 1.00 & $\mathrm{NaN}$ & 1.00 & - \\
\hline & Recreation & 24,204 & 0 & 10,439 & 0 & 0.57 & $\mathrm{NaN}$ & 1.00 & - \\
\hline & Drinking water & 24,204 & 0 & 686 & 0 & 0.97 & $\mathrm{NaN}$ & 1.00 & - \\
\hline & Drinking water (hotspot) & 5,126 & 19,078 & 0 & 0 & 1.00 & 1.00 & 1.00 & 1.00 \\
\hline & Climate regulation & 24,204 & 0 & 5,460 & 0 & 0.77 & $\mathrm{NaN}$ & 1.00 & - \\
\hline \multicolumn{10}{|l|}{ ESS $1 /$ forest } \\
\hline \multirow[t]{4}{*}{ functions } & Biodiversity & 24,204 & 0 & 4 & 0 & 1.00 & $\mathrm{NaN}$ & 1.00 & - \\
\hline & Recreation & 24,204 & 0 & 10,439 & 0 & 0.57 & $\mathrm{NaN}$ & 1.00 & - \\
\hline & Drinking water & 24,204 & 0 & 686 & 0 & 0.97 & $\mathrm{NaN}$ & 1.00 & - \\
\hline & Drinking water (hotspot) & 5,126 & 19,078 & 0 & 0 & 1.00 & 1.00 & 1.00 & 1.00 \\
\hline \multicolumn{10}{|l|}{ ESS 2/forest } \\
\hline \multirow[t]{2}{*}{ functions } & Biodiversity & 7,576 & 16,628 & 0 & 16,624 & 1.00 & 0.00 & 0.31 & 1.00 \\
\hline & Recreation & 6,956 & 17,248 & 3,248 & 10,057 & 0.53 & 0.42 & 0.27 & 0.69 \\
\hline \multicolumn{10}{|l|}{ ESS 3/forest } \\
\hline \multirow[t]{4}{*}{ functions } & Biodiversity & 5,898 & 18,306 & 0 & 18,302 & 1.00 & 0.00 & 0.24 & 1.00 \\
\hline & Recreation & 24,204 & 0 & 10,439 & 0 & 0.57 & $\mathrm{NaN}$ & 1.00 & - \\
\hline & Drinking water & 24,204 & 0 & 686 & 0 & 0.97 & $\mathrm{NaN}$ & 1.00 & - \\
\hline & Climate regulation & 24,204 & 0 & 5,460 & 0 & 0.77 & $\mathrm{NaN}$ & 1.00 & - \\
\hline \multicolumn{10}{|l|}{ ESS 4/forest } \\
\hline \multirow[t]{3}{*}{ functions } & Biodiversity & 9,558 & 14,646 & 0 & 14,642 & 1.00 & 0.00 & 0.39 & 1.00 \\
\hline & Recreation & 11,026 & 13,178 & 5,963 & 8,702 & 0.46 & 0.34 & 0.37 & 0.43 \\
\hline & Drinking water & 1,008 & 23,196 & 0 & 22,510 & 1.00 & 0.03 & 0.04 & 1.00 \\
\hline \multicolumn{10}{|l|}{ ESS 5/forest } \\
\hline \multirow[t]{2}{*}{ functions } & Biodiversity & 17,661 & 6,543 & 0 & 6,539 & 1.00 & 0.00 & 0.73 & 1.00 \\
\hline & Recreation & 7,024 & 17,180 & 2,344 & 9,085 & 0.67 & 0.47 & 0.34 & 0.78 \\
\hline \multicolumn{10}{|l|}{ ESS $2 \& 3 /$ forest } \\
\hline \multirow[t]{2}{*}{ functions } & Biodiversity & 10,250 & 20,980 & 0 & 20,976 & 1.00 & 0.00 & 0.42 & 1.00 \\
\hline & Recreation & 24,204 & 17,248 & 10,439 & 17,248 & 0.57 & 0.00 & 1.00 & - \\
\hline ESS 2\&4/forest & & & & & & & & & \\
\hline functions & Biodiversity & 18,102 & 20,114 & 5,058 & 20,110 & 0.72 & 0.00 & 0.54 & 1.00 \\
\hline & Recreation & 12,859 & 19,081 & 6,628 & 11,225 & 0.48 & 0.41 & 0.45 & 0.75 \\
\hline ESS $2 \& 5 /$ forest & & & & & & & & & \\
\hline functions & Biodiversity & 18,102 & 17,069 & 0 & 17,065 & 1.00 & 0.00 & 0.75 & 1.00 \\
\hline & Recreation & 10,248 & 20,472 & 4,145 & 11,480 & 0.60 & 0.44 & 0.44 & 0.86 \\
\hline ESS $3 \& 4 /$ forest & & & & & & & & & \\
\hline functions & Biodiversity & 13,794 & 22,542 & 0 & 22,538 & 1.00 & 0.00 & 0.57 & 1.00 \\
\hline & Recreation & 24,204 & 13,178 & 10,439 & 8,702 & 0.57 & 0.34 & 1.00 & 0.43 \\
\hline ESS $3 \& 5 /$ forest & & & & & & & & & \\
\hline functions & Biodiversity & 18,409 & 19,054 & 0 & 19,050 & 1.00 & 0.00 & 0.76 & 1.00 \\
\hline & Recreation & 24,204 & 17,180 & 10,439 & 9,085 & 0.57 & 0.47 & 1.00 & 0.78 \\
\hline ESS $4 \& 5 /$ forest & & & & & & & & & \\
\hline functions & Biodiversity & 17,793 & 14,778 & 0 & 14,774 & 1.00 & 0.00 & 0.74 & 1.00 \\
\hline & Recreation & 12,972 & 19,126 & 6,436 & 10,558 & 0.50 & 0.45 & 0.47 & 0.82 \\
\hline ESS & & & & & & & & & \\
\hline $2,3 \& 4 /$ forest & & & & & & & & & \\
\hline functions & Biodiversity & 15,045 & 23,215 & 0 & 23,211 & 1.00 & 0.00 & 0.62 & 1.00 \\
\hline & Recreation & 24,204 & 19,081 & 10,439 & 14,605 & 0.57 & 0.23 & 1.00 & 0.43 \\
\hline ESS & & & & & & & & & \\
\hline $2,3 \& 5 /$ forest & & & & & & & & & \\
\hline functions & Biodiversity & 18,615 & 21,215 & 0 & 21,211 & 1.00 & 0.00 & 0.77 & 1.00 \\
\hline & Recreation & 24,204 & 20,472 & 10,439 & 12,377 & 0.57 & 0.40 & 1.00 & 0.78 \\
\hline ESS & & & & & & & & & \\
\hline $3,4 \& 5 /$ forest & & & & & & & & & \\
\hline functions & Biodiversity & 18,445 & 22,638 & 0 & 22,634 & 1.00 & 0.00 & 0.76 & 1.00 \\
\hline & Recreation & 24,204 & 19,126 & 10,439 & 11,031 & 0.57 & 0.42 & 1.00 & 0.78 \\
\hline ESS & & & & & & & & & \\
\hline $2,3,4 \& 5 /$ forest & & & & & & & & & \\
\hline functions & Biodiversity & 18,645 & 23,225 & 0 & 23,221 & 1.00 & 0.00 & 0.77 & 1.00 \\
\hline & Recreation & 24,204 & 21,379 & 10,439 & 12,387 & 0.57 & 0.42 & 1.00 & 0.86 \\
\hline
\end{tabular}


Table A1.2. CICES sections, divisions and classes for ESS mentioned in the workshop, short names used in the text and corresponding forest functions.

\begin{tabular}{|c|c|c|c|c|}
\hline CICES section & CICES division & classification used & CICES class & corresponding forest functions \\
\hline \multirow{7}{*}{ Provisioning } & \multirow{4}{*}{ Nutrition } & \multirow{3}{*}{ Food } & Reared animals and their outputs & NA \\
\hline & & & Wild plants, algae and their outputs & \multirow{2}{*}{ use function } \\
\hline & & & Wild animals and their outputs & \\
\hline & & Drinking Water & Ground water for drinking & water protection \\
\hline & \multirow[t]{2}{*}{ Materials } & \multirow[t]{2}{*}{ Timber } & $\begin{array}{l}\text { Fibres and other materials from plants, algae and } \\
\text { animals for direct use or processing } \\
\begin{array}{l}\text { Materials from plants, algae and animals for agricultural } \\
\text { use }\end{array} \\
\end{array}$ & use function \\
\hline & & & Genetic materials from all biota & protection genetic ressources \\
\hline & Energy & Fuelwood & Plant-based resources & use function \\
\hline \multirow{9}{*}{$\begin{array}{l}\text { Regulation \& } \\
\text { Maintenance }\end{array}$} & \multirow{4}{*}{$\begin{array}{c}\text { Mediation of waste, } \\
\text { toxics and other } \\
\text { nuisances }\end{array}$} & \multirow{4}{*}{ Imission control } & $\begin{array}{l}\text { Filtration/sequestration/storage/accumulation by micro- } \\
\text { organisms, algae, plants, and animals }\end{array}$ & \multirow{2}{*}{ local immission control } \\
\hline & & & \multirow{3}{*}{ Mediation of smell/noise/visual impacts } & \\
\hline & & & & noise protection \\
\hline & & & & visual protection \\
\hline & Mediation of flows & flood protection & Flood protection & \multirow{2}{*}{ water protection } \\
\hline & \multirow{4}{*}{$\begin{array}{c}\text { Maintenance of } \\
\text { physical, chemical, } \\
\text { biological } \\
\text { conditions }\end{array}$} & \multirow{4}{*}{$\begin{array}{c}\text { Mediation of climate and } \\
\text { water quality }\end{array}$} & Chemical condition of freshwaters & \\
\hline & & & $\begin{array}{l}\begin{array}{l}\text { Global climate regulation by reduction of greenhouse gas } \\
\text { concentrations }\end{array} \\
\end{array}$ & NA \\
\hline & & & & regional climate protection \\
\hline & & & & local climate protection \\
\hline \multirow{4}{*}{ Cultural } & \multirow{4}{*}{\begin{tabular}{|} 
Physical and \\
intellectual \\
interactions with \\
biota, ecosystems, \\
and land- \\
/seascapes \\
[environmental \\
settings]
\end{tabular}} & \multirow{4}{*}{ recreation } & $\begin{array}{l}\text { Experiential use of plants, animals and land-/seascapes in } \\
\text { different environmental settings } \\
\text { Physical use of land-/seascapes in different } \\
\text { environmental settings }\end{array}$ & \multirow[t]{2}{*}{ recreation } \\
\hline & & & Educational & \\
\hline & & & Heritage, cultural & $\begin{array}{l}\text { historical forest management/ } \\
\text { cultural monument }\end{array}$ \\
\hline & & & Aesthetic & landscape aesthetics \\
\hline
\end{tabular}

